\title{
Differentiation of Benign and Malignant Kidney Masses via Inflammation Parameters
}

\section{Benign ve Malign Böbrek Kitlelerinin Enflamasyon Markerlarıyla Ayrımı}

\section{(D) Murat Demir, (D) Recep Eryılmaz, (D) Rahmi Aslan, (D) Kasım Ertaş, (D) Kerem Taken}

Van Yüzüncü Yıl University Faculty of Medicine, Department of Urology, Van, Turkey

\section{Abstract}

Objective: Despite the recent advances in imaging methods, the rate of $10-20 \%$ is still insufficient in predicting the pathology of renal masses. Therefore, we aimed to examine whether hematological inflammatory markers were useful in predicting pathology outcome.

Method: One hundred sixteen patients who were operated for kidney mass between January 2010 and October 2020 were included in the study. Retrospectively, preoperative platelets, neutrophils, lymphocytes and their rates were compared with pathology results.

Results: The mean age of 116 patients included in the study was $55.36 \pm 13.93$ years. While pathology results of $26(22.4 \%)$ patients were benign, results of $90(77.6 \%)$ patients were malignant. The neutrophil and neutrophil lymphocyte ratio were significantly lower in the benign group. According to the Fuhrman grade of renal cell carcinoma, platelet and platelet lymphocyte ratio were higher in aggressive groups, whereas lymphocyte count was lower.

Conclusion: Hematological inflammatory markers are useful in predicting the pathology outcome of kidney masses before surgery.

Keywords: Blood platelets, kidney neoplasms, lymphocytes, neutrophils

\section{Öz}

Amaç: Görüntüleme yöntemlerindeki son gelişmelere rağmen, böbrek kitlelerinin patolojisini tahmin etmede hala \%10-20 oranı yetersizdir. Bu nedenle, hematolojik enflamatuvar belirteçlerin patoloji sonucunu tahmin etmede yararlı olup olmadığını incelemeyi amaçladık.

Yöntem: Ocak 2010 ile Ekim 2020 tarihleri arasında böbrek kitlesi nedeniyle opere edilen 116 hasta çalışmaya dahil edildi. Retrospektif olarak preoperatif trombosit, nötrofiller, lenfosit sayıları ve oranları patoloji sonuçları ile karşılaştııılı.

Bulgular: Çalışmaya alınan 116 hastanın yaş ortalaması 55,36 $\pm 13,93$ yıl idi. Yirmi altı $(\% 22,4)$ hastanın patoloji sonuçları benign iken 90'ı $(\% 77,6)$ malign idi. Nötrofil sayısı ve nötrofil lenfosit oranı benign grupta anlamlı olarak daha düşüktü. Renal hücreli karsinomlu hastalarda yüksek Fuhrman derecelerinde trombosit sayısı ve trombosit lenfosit oranı daha yüksek iken lenfosit sayısı ise daha düşüktü.

Sonuç: Hematolojik enflamatuvar belirteçler, ameliyattan öncesi böbrek kitlelerinin patoloji sonucunu tahmin etmede yararlıdır.

Anahtar kelimeler: Böbrek neoplazmaları, kan trombositleri, lenfosit, nötrofil

\section{Introduction}

Among urogenital tumors, renal tumors are seen in third place in order of incidence and in first place in order of mortality (1). Patients present to the clinic with the complaints of flank pain, palpable mass, and hematuria. However, this triad is present in $5-10 \%$ of cases and is associated with advanced disease (2).

Today, renal masses are incidentally detected earlier, thanks to the increasing use and the quality of imaging methods (3). Accordingly, surgical treatments give more positive results (4). Despite these improvements in radiological imaging, it is still insufficient to predict pathology of kidney tumors. In $10-20 \%$ of patients, especially in benign masses such as angiomyolipoma which has poor adipose tissue and oncocytoma, the distinction between benign and malignant cannot be made (5). For this reason, additional data are needed to predict the outcome of pathology before surgery.

Many studies have shown that systemic inflammation is effective in the formation and progression of

Address for Correspondence: Murat Demir, Van Yüzüncü Yıl University Faculty of Medicine, Department of Urology, Van, Turkey

E-mail: urologmurat72@gmail.com ORCID: orcid.org/0000-0001-5029-8800 Received: 16.02.2021 Accepted: 26.07.2021

Cite this article as: Demir M, Eryılmaz R, Aslan R, Ertaş K, Taken K. Differentiation of Benign and Malignant Kidney Masses via Inflammation Parameters. Bagcilar Med Bull 2021;6(3):276-279

${ }^{\odot}$ Copyright 2021 by the Health Sciences University Turkey, Bagcilar Training and Research Hospital Bagcilar Medical Bulletin published by Galenos Publishing House. 
cancer. Systemic inflammation increases in the number of platelets and neutrophils, and decreases in the number of lymphocytes. It has been shown in some studies that these hematological values can be used to predict prognosis in kidney tumors (6). However, we did not find any study in the literature regarding the use of these parameters to predict malignancy.

In this study, it was evaluated whether platelet, neutrophil, lymphocyte and their ratios could be used to predict pathology results in kidney masses.

\section{Materials and Methods}

After getting approval from the Local Ethics Committee (Van Yüzüncü Yll University, KAEK, decision number: 2020/09-21, date: 04.12.2020) and obtaining consent form from patients, in accordance with the latest Helsinki Declaration, the files of patients who underwent radical and partial nephrectomy in our clinic between January 2010 and October 2020 were retrospectively reviewed. Age, gender, tumor side, diameter, operation, pathology results of the patients, platelet, neutrophil, lymphocyte values and ratios, platelet/lymphocyte (PLR), platelet/ neutrophil (PNR), and neutrophil/lymphocyte rate (NLR) were evaluated together with pathology results. Fuhrman system was used for tumor grades. Patients with chronic diseases that could alter inflammatory parameters, such as diabetes mellitus, chronic kidney disease, chronic liver disease, sarcoidosis, amyloidosis, and inflammatory bowel diseases, were excluded from the study. And those using drugs such as steroid and anti-inflammatories, which could alter inflammatory parameters, were excluded from the study.

\section{Statistical Analysis}

Age, tumor size, neutrophil, lymphocyte, platelet, PLR, NLR, and PNR were expressed as mean and standard deviation, and gender, direction, and pathology results were expressed as numbers and percentages. One-Way analysis of variance was used to compare the groups in terms of inflammatory parameters. Statistical significance level was taken as $5 \%$ in calculations and SPSS (ver.21) statistical package program was used for analyses.

\section{Results}

The mean age of 116 patients included in the study at the time of diagnosis was $55.36 \pm 13.93$ years. Seventy $(60.3 \%)$ of the patients were male and 46 (39.7\%) were female. Tumor size was $6.62 \pm 4.20 \mathrm{~cm}$ on average. Radical nephrectomy was applied to 77 of the patients (66.4\%), and partial nephrectomy to 39 (33.6\%) of the patients. While $90(77.6 \%)$ of the pathology results were malignant, $26(22.4 \%)$ of them were benign. Of the malignant pathologies, 86 were renal cell carcinoma (RCC), and 4 were transitional cell carcinomas. According to the Fuhrman grading of RCCs, 26 were grade 1,38 were grade 2,17 were grade 3 , and 5 were grade 4 . Of the benign pathologies, 12 were oncocytomas, 6 were angiomyolipoma, 4 were xanthogranulomatous pyelonephritis, and 4 were multicystic lesions. The preoperative platelet was $268,700 \pm 82,560$, neutrophil was $5,430 \pm 2,220$, lymphocyte was $2,140 \pm 750$, PNR ratio was $55.21 \pm 21.55$, PLR ratio was $140.99 \pm 70.88$, NLR ratio was $2.82 \pm 1.53$. The comparison of inflammatory parameters with pathology results are shown in Table 1, 2 .

\section{Discussion}

Inflammation plays a key role in cancer (7). Cytokines and growth factors produced together with systemic inflammation trigger carcinogenesis and cause tumor development and proliferation. The inflammatory role of chronic inflammation in hepatocellular carcinoma caused by viral infection, in bladder cancer by chronic stones and infection, and in colon cancer by inflammatory bowel disease has been demonstrated (8-10).

After learning the role of inflammation in cancer, it has become important to show systemic inflammation in a correct, easy and cheap way. Complete blood count (CBC) shows systemic inflammation very easily, quickly, accurately and at a low cost for the patient and physician with many parameters it includes $(11,12)$. The most important inflammatory markers of CBC are neutrophils, lymphocytes and thrombocytes. While neutrophilia is associated with chronic inflammation in cancer, studies have shown that lymphopenia and thrombocytosis are

\begin{tabular}{|c|c|c|c|}
\hline & Benign & Malignant & $\mathbf{p}$ \\
\hline $\begin{array}{l}\text { Platelet } \\
(\times 1000 / \mathrm{uL})\end{array}$ & $254.23 \pm 68.85$ & $272.88 \pm 86.00$ & 0.3 \\
\hline $\begin{array}{l}\text { Neutrophil } \\
(\times 1000 / u L)\end{array}$ & $4.38 \pm 1.13$ & $5.73 \pm 2.37$ & $0.006^{a}$ \\
\hline $\begin{array}{l}\text { Lymphocyte } \\
\text { (×1000/uL) }\end{array}$ & $2.23 \pm 0.63$ & $2.12 \pm 0.78$ & 0.5 \\
\hline PNR & $61.61 \pm 21.01$ & $53.36 \pm 21.46$ & 0.085 \\
\hline PLR & $124.64 \pm 59.82$ & $145.72 \pm 73.39$ & 0.182 \\
\hline NLR & $2.17 \pm 1.05$ & $3.00 \pm 1.60$ & $0.014^{b}$ \\
\hline
\end{tabular}

One-Way analysis of variance, PNR: Platelet neutrophil ratio, PLR: Platelet lymphocyte ratio, NLR: Neutrophil lymphocyte ratio, aNeutrophil count and ${ }^{b} N L R$ significantly lower in benign group 
Table 2. Comparison of Fuhrman grades with hematological parameters

\begin{tabular}{llllll} 
& Grade 1 & Grade 2 & Grade 3 & Grade 4 & p \\
\hline Platelet $(\times 1000 / \mathrm{uL})$ & $244.42 \pm 58.18$ & $252.45 \pm 61.79$ & $318.41 \pm 103.75$ & $355.60 \pm 131.78$ & $0.001^{\mathrm{a}}$ \\
Neutrophil $(\times \mathbf{1 0 0 0} / \mathrm{uL})$ & $5.58 \pm 1.91$ & $5.56 \pm 2.30$ & $5.61 \pm 2.74$ & $6.66 \pm 4.41$ & 0.816 \\
Lymphocyte $(\times \mathbf{1 0 0 0} / \mathrm{uL})$ & $2.47 \pm 0.95$ & $2.01 \pm 0.66$ & $1.99 \pm 0.72$ & $1.66 \pm 0.36$ & $0.041^{\mathrm{b}}$ \\
PNR & $48.51 \pm 18.92$ & $51.68 \pm 19.48$ & $65.09 \pm 28.50$ & $60.48 \pm 17.13$ & 0.072 \\
PLR & $108.74 \pm 37.32$ & $143.14 \pm 73.35$ & $178.22 \pm 91.74$ & $215.66 \pm 64.83$ & $0.002^{\mathrm{c}}$ \\
NLR & $2.59 \pm 1.58$ & $3.00 \pm 1.46$ & $3.13 \pm 1.93$ & $3.90 \pm 1.87$ & 0.358 \\
\hline
\end{tabular}

PNR: Platelet neutrophil ratio, PLR: Platelet lymphocyte ratio, NLR: Neutrophil lymphocyte ratio, One-Way analysis of variance, aPlatelet: Significantly higher platelet count in Fuhrman 3 and 4 groups compared to group 1 and 2, bymphocyte count is significantly higher in Fuhrman 1 than Fuhrman 2, 3, 4, and significantly lower in Fuhrman 4 than Fuhrman 1, 2, 3, cPLR increases significantly in each group as the Fuhrman grade increases

associated with poor prognosis in many types of cancer (11). Also, studies show that CBC inflammation parameters can help in diagnosis. One study indicated that NLR and PLR could be used in some cases to differentiate benign prostatic hyperplasia from prostate cancer (13).

Platelet, one of the systemic inflammation parameters in $\mathrm{CBC}$, is effective in tumor development. Thrombocytes produce these effects through vascular endothelial growth factor, platelet-derived growth factor (PDGF), fibroblast growth factor and transforming growth factor-beta (14). Both absolute neutrophil count and NLR are used as the markers of inflammation. Although neutrophils are the main defenders of the immune system, their increasing numbers both trigger the activation of tumor cells and cause suppression of anti-tumoral mechanisms (15). Neutrophils act through cytokines and growth factors (16). Lymphocytes, another element of the systemic response, inhibit tumor cell proliferation and migration, and kill tumor cells with a cytotoxic effect (17). Lymphocytes can suppress tumor cells through CD3, CD4, CD8, and p46 and improve survival in patients with cancer (2). Many studies have shown that neutrophil and neutrophil-lymphocyte ratios can be used to predict cancer prognosis (18). However, we could not see enough studies in the literature regarding the use of neutrophils to predict preoperative malignancy. In one of these studies, Tangal et al. (19) stated that neutrophillymphocyte ratios were not useful in predicting malignancy and the Fuhrman's degree in kidney masses. However, in our study, both the neutrophil value and the neutrophillymphocyte ratio were found to be significantly higher in the malignant group. It is observed that Tangal et al. (19) did not exclude patients with additional systemic diseases from the study. However, systemic diseases and malignancies change neutrophil and lymphocyte counts (11).

The other hematological parameter of systemic inflammation is lymphocytes. In none of the studies we encountered in the literature, the number of lymphocytes was evaluated alone, and in all studies, it was studied in the form of NLR or PLR. Increased NLR has been reported to be associated with poor prognosis in breast, colorectal, esophagus and prostate cancer (20-23). On the other hand, Karaoğullarından et al. (14) showed in their study that PLR increased in direct proportion to the diameter of the tumor (14). In addition, lymphocytopenia has been associated with poor prognosis in many studies (24). In our study, lymphocyte level was higher in benign tumors. However, it was not statistically significant. It is possible to obtain statistically significant results in studies with higher case series.

The Fuhrman histopathological rating system is the most commonly used method in RCCs today. The importance of Fuhrman core rating in predicting survival was demonstrated in the study of Gudbjartson et al. (25) on 629 patients. Although Viers et al. (26) showed an important relationship between NLR and Fuhrman's degree, no significant results were obtained in the study of Arda et al. (27). In our study, no relationship was found between neutrophil count, NLR and Fuhrman grade. However, in RCC patients, it was observed that platelets increased significantly as the degree of prostitution increased. We observed that the lymphocyte count decreased significantly inversely with the Fuhrman grade and the PLR significantly according to the Fuhrman grade.

The retrospective design and relatively small number of patients are the limitations of our study.

\section{Conclusion}

Systemic inflammation parameters such as neutrophil, lymphocyte and platelet levels can be used to predict postoperative pathology outcomes before surgery.

\section{Ethics}

Ethics Committee Approval: After getting approval from the Local Ethics Committee (Van Yüzüncü Yll University, KAEK, decision number: 2020/09-21, date: 04.12.2020). 
Informed Consent: Informed consent was obtained.

Peer-review: Externally peer-reviewed.

\section{Authorship Contributions}

Concept: M.D., R.E., R.A., K.E., Design: M.D., R.E., K.T., K.E., Data Collection or Processing: M.D., R.E., R.A., Analysis or Interpretation: M.D., K.E., R.A., Literature Search: M.D., K.T., Writing: M.D., K.E., R.E., R.A.

Conflict of Interest: No conflict of interest was declared by the authors.

Financial Disclosure: The author declared that this study has received no financial support.

\section{References}

1. Li W, Cheng Y, Cheng Y, Ren H, Han N. Clinical efficacy of radical nephrectomy versus nephron-sparing surgery on localized renal cell carcinoma. Eur J Med Res 2014;19(1):1-6.

2. Lee CT, Katz J, Fearn PA, Russo P. Mode of presentation of renal cell carcinoma provides prognostic information. Urol Oncol 2002;7(4):135-140.

3. Şahin H, Akarken İ. Böbrek Tümörlerinde Etiyoloji, Klinik Tanı ve Evrelemesi. Turk Klin Urol 2019;12(4):1-9.

4. King SC, Pollack LA, Li J, King JB, Master VA. Continued increase in incidence of renal cell carcinoma, especially in young patients and high grade disease: United States 2001 to 2010. J Urol 2014;191(6):1665-1670

5. Morra MN, Das S. Renal oncocytoma: a review of histogenesis, histopathology, diagnosis and treatment. J Urol 1993;150(2 Pt 1):295-302.

6. Grivennikov SI, Greten FR, Karin M. Immunity, inflammation, and cancer. Cell 2010;140(6):883-899.

7. Yildirim M, Kılınç Y, Ceyhan A. Behçet hastalığı patogenezindeki yenilikler. Suleyman Demirel Univ Tıp Fak Derg 2009;16(3):29-34.

8. Waldner MJ, Neurath MF. Colitis-Associated Cancer: the role of $t$ cells in tumor development. Semin Immunol 2009;31(2):249-256.

9. Karin M. Nuclear factor-kappaB in cancer development and progression. Nature 2006;441(7092):431-436.

10. Wu S, Rhee KJ, Albesiano E, Rabizadeh S, Wu X, Yen HR, et al. A human colonic commensal promotes colon tumorigenesis via activation of $\mathrm{t}$ helper type $17 \mathrm{t}$ cell responses. Nat Med 2009;15(9):1016-1022.

11. Howard R, Kanetsky PA, Egan KM. Exploring the prognostic value of the neutrophil-to-lymphocyte ratio in cancer. Sci Rep 2019;9(1):1-10.

12. Duran İ, Avcı V, Nazik S, Altun E. Çocukluk çağı apandisit tanısında nötrofil lenfosit oranı ve trombosit lenfosit oranı. Turk Klin Biyokim Derg 2017;15(1):1-7.

13. Kaynar M, Yildirim ME, Gul M, Kilic O, Ceylan K, Goktas S. Benign prostatic hyperplasia and prostate cancer differentiation via platelet to lymphocyte ratio. Cancer Biomark 2015;15(3):317-323.
14. Karaoğullarından Ü, Akkız H, Kuran S, Uskudar O, Taskaynatan H, Delik A. The relationship between thrombocyte lymphocyte ratio with tumor morphology and alpha fetoprotein in patients with hepatocellular carcinoma. Turk J Fam Med and Primary Care 2020;14(2):230-235.

15. Ishizuka M, Nagata H, Takagi K, Iwasaki Y, Kubota K. Combination of platelet count and neutrophil to lymphocyte ratio is a useful predictor of postoperative survival in patients with colorectal cancer. Br J Cancer 2013;109(2):401-407.

16. Kusumanto YH, Dam WA, Hospers GA, Meijer C, Mulder NH. Platelets and granulocytes, in particular the neutrophils, form important compartments for circulating vascular endothelial growth factor. Angiogenesis 2003;6(4):283-287.

17. Mantovani A, Allavena P, Sica A, Ballkwill F. Cancer related inflammation. Nature 2008;454(7203):436-444.

18. Teramukai S, Kitano T, Kishida Y, Kawahara M, Kubota K, Komuta $\mathrm{K}$, et al. Pretreatment neutrophil count as an independent prognostic factor in advanced non-small-cell lung cancer: an analysis of Japan Multinational Trial Organisation LC00-03. Eur J Cancer 2009;45(11):1950-1958.

19. Tangal S, Kutsal Ö, Yiğman M, Haliloğlu, A. Relation of neutrophil lymphocyte ratio with tumor characteristics in localized kidney tumors. New J Urol 2018;13(1):12-15.

20. Keizman D, Gottfried M, Ish-Shalom M, Maimon N, Peer A, Neumann A, et al. Pretreatment neutrophil-to-lymphocyte ratio in metastatic castration-resistant prostate cancer patients treated with ketoconazole: association with outcome and predictive nomogram. Oncologist 2012;17(12):1508-1514.

21. Mallappa S, Sinha A, Gupta S, Chadwick S. Preoperative neutrophil to lymphocyte ratio $>5$ is a prognostic factor for recurrent colorectal cancer. Colorectal Dis 2013;15(3):323-328.

22. Sharaiha R, Halazun K, Mirza F, Port J, Lee P, Neugut A, et al. Elevated preoperative neutrophil: lymphocyte ratio as a predictor of postoperative disease recurrence in esophageal cancer. Ann Surg Oncol 2011;18(12):3362-3369.

23. Forget P, Machiels J, Coulie P, Berliere M, Poncelet A, Tombal B, et al. Neutrophil: lymphocyte ratio and intraoperative use of ketorolac or diclofenac are prognostic factors in different cohorts of patients undergoing breast, lung, and kidney cancer surgery. Ann Surg Oncol 2013;20(3):650-660.

24. Fogar P, Sperti C, Basso D, Sanzari M, Greco E, Davoli C, et al. Decreased total lymphocyte counts in pancreatic cancer: an index of adverse outcome. Pancreas 2006;32(1):22-28.

25. Gudhjartsson T, Hardarson S, Petursdottir V, Thoroddsen A, Magnusion J, Einarsson GV. Histological subtyping and nuclear gradingoi renal cell carcinoma and their implications for survival: a retrospective nation-wide study of 629 patients. Eur Urol 2005;48(4):593-600.

26. Viers B, Thompson R, Boorjian S, Lohse C, Leibovich B, Tollefson M. Preoperative neutrophil-lymphocyte ratio predicts death among patients with localized clear cell renal carcinoma undergoing nephrectomy. Urol Oncol 2014;32(8):1277-1284.

27. Arda E, Yuksel I, Cakiroglu B, Akdeniz E, Cilesiz N. Valuation of neutrophil/lymphocyte ratio in renal cell carcinoma grading and progression. Cureus 2018;10(1):1-9. 